\title{
GTR-上皮下結合組織移植併用法を用いた突出歯根に対する根面被覆
}

申 基喆, 渡辺和志, 石澤正晃, 熊谷敬史, 小林之直, 山村加奈子, 西田栄昭, 東 高史, 星原英吉，春藤幸伸*，鈴木玲爾*，俞 時英*，辰巳順一，宮田 隆

\section{Exposed root coverage for facially prominent root utilizing the combination of GTR and subepithelial connective tissue graft}

Kitetsu Shin, Kazuyuki Watanabe, Masaaki Ishizawa, Takashi Kumagai, Yukinao Kobayashi, Kanako Yamamura, Hideaki Nishida, Takashi Azuma, Eiyoshi Hoshihara, Yukinobu Syundo*, Reiji Suzuki*, Tokihide Yu*, Junichi Tatsumi and Takashi Miyata

Marginal tissue recession related to periodontal disease or tooth mal-position, such as facially prominent tooth can cause to root sensitivity, root caries, and esthetically unacceptable root exposures. Accordingly, marginal tissue recessions were treated by root coverage procedures in order to improve these problems, and predictable clinical results have been reported significantly. However, it had been considered that the root coverage for facially prominent tooth was difficult to obtain the adequate clinical results because of as disadvantage.

The purpose of this study was to demonstrate the efficacy of root coverage technique utilizing the combination of GTR and subepithelial connective tissue graft in the treatment of marginal tissue recession of facially prominent exposed root. Bilateral maxillary canines that prominent facially with deep and wide marginal tissue recession were utilized in this study. This procedure was started on the reflected full thickness flap, then e-PTFE membrane was placed over the exposed root surface. The flap was extentional replaced to coronally in the situation of cover the membrane. Six weeks after the surgery, the flap was reopened for the purpose of remove the e-PTFE membrane. This procedure then continue the subepithelial connective tissue from the donor site at palate was grafted onto the newly formed tissue covering the exposed root. The periodontal parameters of the results were measured 12 months later. In the results, the probing attachment gain of $5.5 \mathrm{~mm}$ in the right, and $4.5 \mathrm{~mm}$ in the left side were measured. The keratinized tissue was obtained increasing of $4.5 \mathrm{~mm}$ in the right, and also increasing of $3.0 \mathrm{~mm}$ in the left side. And the exposed root surfaces were completely covered with sufficient keratinized tissue. This results suggested that it is significant predictable procedure for the case of marginal tissue recession with facially prominent exposed tooth.

Key words : marginal tissue recession, root coverage, guided tissue regeneration, subepithelial connective tissue graft, periodontal plastic surgery

明海大学歯学部歯周病学講座, “研修センター

Department of Periodontology, ${ }^{*}$ Continual Education Center

Meikai University School of Dentistry 


\section{緒 言}

辺縁歯肉の退縮による歯根露出は, 根面䠛蝕や象牙質の 知覚過敏の誘因となるばかりではなく, 上顎前歯部に生じ た場合では審美性の低下を招き, 患者の精神的劣等感につ ながる場合もある1 (4).このため, 前歯部の審美改善を目 的に, 露出歯根面の被覆を行う頻度も年々增加してきてお り, Miller) は根面被覆を含めた従来からの歯肉歯槽粘膜形 成術を, さらに広い範疇でとらえ, Periodontal plastic surgery として新たに定義した．歯肉退縮の外科的治療法としての 露出歯根面の被覆術は, Langer $ら^{6)}$ の上皮下結合組織移植 の根面被覆への応用以来, 予知性の高い方法として臨床に 応用され, 数多くの改良法7一11)も報告されている.ささらに 最近では, 組織誘導再生 (guided tissue regeneration；GTR) 法12 18) が根面被覆に応用されるようになり，歯周組織の 再生を期待できる根面被覆法として注目されている.

一方, 種々の根面被覆法はそれぞれの方法によって適応 症に限界があることも事実であり，一般に確実な根面被覆 を達成させるためには, 歯間隣接部の硬, 軟組織の亦失が ない, 歯列不正がないことなどが必要条件 19 とされている. しかし，日常臨床においてはその条件が十分に備わったケ 一スはむしろまれであり，歯根の唇側への突出や歯間部組 織の喪失を伴う場合が多く，完全な根面被覆を困難にして いる，そこでここでは，根面被覆を困難にしている要因の 一つである唇側への突出歯根の根面被覆に注目し，その可 能性を検討することを目的に，両側性に唇側に突出した上 顎犬歯の歯根露出を認めた患者に対し，GTR 法と上皮下 結合組織移植を併用した根面被覆を行い，その術式と効果 について考察した。

\section{方 法}

\section{1. 被験者}

被験者は 45 歳の女性で，上顎両側犬歯唇側歯頸部の冷水 痛とブラッシング時の疼痛を訴えて来院した. 現症として, 両側上顎犬歯は萌出時から唇側に突出しており, 矯正治療 を勧められたが治療期間が長くなるという理由から行わな かった。その後，同部の歯肉退縮に気づいたが放置してい た. 最近になって, 同部の冷水痛とブラッシング時の疼痛 を認めるようになり来院に至る．全身的既往歴に特記すべ き事項は認められない．初診時の口腔内所見として，両側 上顎犬歯は唇側傾斜しており，辺縁歯肉退縮による歯根露 出を認める．患者はこれまでに歯周外科処置を受けた既往 はないが，外科処置に際して特に問題となるような全身疾 患は認められなかった。また，施術にあたっては用いる術
式や治療効果について説明し，あらかじめ患者の理解と同 意を得た. 歯周外科前処置として, プラークコントロール， スケーリングおよびルートプレーニングなどの歯周基本治 療を行った。

\section{GTR-上皮下結合組織移植併用法の術式}

GTR-上皮下結合組織移植併用法は，非吸収性の ePTFE (expanded polytetrafluoroethylene) 膜を使用するため, 2 度の 外科手術を必要とする。すなわち，一次手術として $\mathrm{ePTFE}$ 膜の設置を行い，露出根面上に新生組織を形成させる。そ の際に剥離したフラップは $\mathrm{ePTFE}$ 膜を完全に被覆するため に，減張切開を用いて大きく歯冠側に伸展される.そして, 一次手術 6 週後にリエントリー手術を行いePTFE 膜の除去 および新生組織上への遊離結合組織移植を行う。そしてこ こでは,一度歯冠側へ伸展したフラップを再び術前の位置, すなわち根尖側に戻した状態で縫合する，以下にその術式 を示す。

1) 一次手術

・切開と全層フラップの剥離

・露出根面の平坦形成とルートプレーニング

・ ePTFE膜のトリミングと固定

・減張切開による全層フラップの歯冠側への伸展

・全層フラップの縫合

2) 二次手術 (一次手術後 6 週)

・切開と全層フラップの剥離

・ ePTFE膜の除去と新生組織の確認

・遊離結合組織移植片の採取

・新生組織上への遊離結合組織の移植

・全層フラップの復位と縫合

\section{GTR-上皮下結合組織移植併用法による根面被覆の治 療効果の判定方法}

治療効果の判定は, 術後の歯肉外形態や色調および性状 などの臨床所見, 術前および術後 12 か月の歯周病学的パラ メーターを測定し, その測定值の変化量から治療効果の判 定を行った．なお，歯周病学的パラメーターとしては,

（1）歯周ポケット深さ (probing pocket depth；PD)

（2）プロービングアタッチメントレベル (probing attachment level ; PAL)

（3）重直的歯肉退縮量（recession depth；RD）

（4）角化組織の幅 (keratinized tissue width ; KTW) とし，これらをアクリリックレジン製の測定用ステントを ガイドに用いて測定した（図 1). 歯周基本治療終了後の 歯周外科処置前の歯周病学的パラメーターを表 1 に示す. 


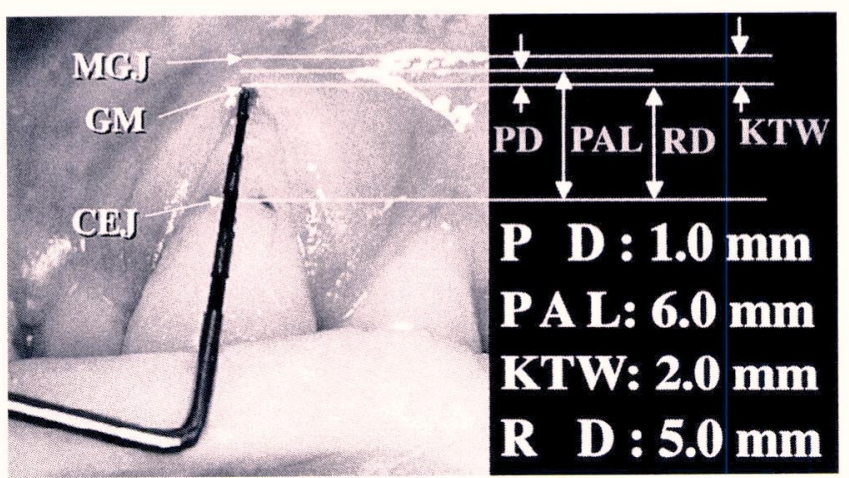

図 1 歯周病学的パラメーターとその計測点

測定値は左側上顎犬歯の術前の値を示す

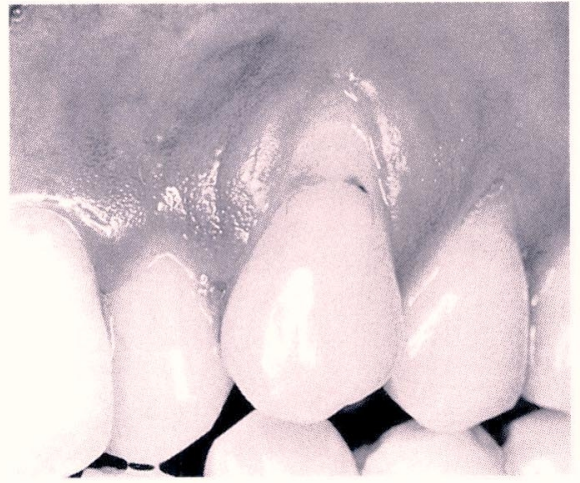

図2 左側上顎犬歯の術前の状態. 歯根の唇側 への突出を伴った深く, 広い歯肉退縮を 認める

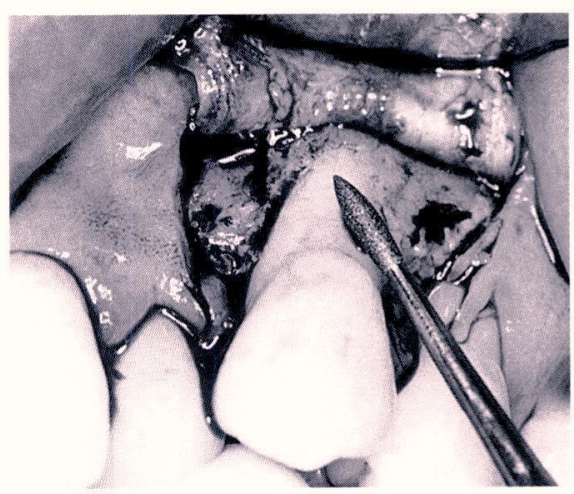

図 3 歯根の突出が著しいため, 露出根面の形 態修正は歯根面がやや平坦になる程度 にとどめる
表 1 術前における $3 \mid 3$ の歯周病学的パラメーター $(\mathrm{mm})$

\begin{tabular}{|c|c|c|}
\hline 歯周病学的パラメーター & $3\rfloor$ & $\lfloor 3$ \\
\hline $\mathrm{PD}$ & 1.5 & 1.0 \\
$\mathrm{PAL}$ & 6.0 & 6.0 \\
$\mathrm{RD}$ & 4.5 & 5.0 \\
$\mathrm{KTW}$ & 2.0 & 2.0 \\
\hline
\end{tabular}

PD : probing pocket depth

PAL : probing attachment level

$\mathrm{RD}$ : recession depth

KTW : keratinized tissue width
両側犬歯ともに術前は $6.0 \mathrm{~mm}$ のプロービングアタッチメ ントレベル， $2.0 \mathrm{~mm}$ の角化組織の幅を認めた。また，垂 直的歯肉退縮量は左側犬歯で $5.0 \mathrm{~mm}$, 右側では $4.5 \mathrm{~mm}$ あった。

\section{4. 治療経過}

GTR-上皮下結合組織移植併用法の施術はRDが大きく, かつ知覚過敏の著明であった左側上顎犬歯に対して行い, その後に右側犬歯に対して行うこととした. 左側犬歯の術 前の状態は図2に示すが, RDは $5.0 \mathrm{~mm}, \mathrm{PAL} 6.0 \mathrm{~mm}$ あり, 歯根の突出により水平的にも広い歯根露出を呈して いる.

\section{1) 一次手術}

\section{（1）切開と全層フラップの剥離}

浸潤麻酔の後左側犬歯唇側に歯肉溝内切開，両側歯間乳 頭を含んだ位置での垂直切開を行う．全層フラップは，露 出歯根最根尖側端を少なくとも $3 \mathrm{~mm}$ 超えた位置まで十分 に剥離する必要がある。
（2）露出根面の平坦形成とルートプレーニング

フラップの剥離後, 露出根面周囲の肉芽組織はすべて取 り除いておく. 通常は露出根面は周囲歯槽骨と移行的にな るまで回転切削器具を用いて平坦に形成しておくが, 歯根 の突出のため, 表面がやや平坦になる程度にとどめておく (図３）。形成した根面は，十分にルートプレーニングして お

(3) ePTFE膜のトリミングと固定

露出根面に適した大きさ, 形態の ePTFE膜（ゴアテック スGTRメンブレン®；ジャパンゴアテックス社，東京）を 試適し, 露出根面よりも $3 \mathrm{~mm}$ 程度広くなるようにトリミン グし, 膜のカラー部分を被験歯のセメントーエナメル境より もやや歯冠側に位置するようにして縫合固定する (図 4).

（4）減張切開による全層フラップの歯冠側への伸展と縫 合

全層フラップの内面基底部に新たに部分層フラップを形 成することにより，フラップの歯冠側への伸展を容易にさ せる．歯冠側への伸展は, フラップが緊張することなく 


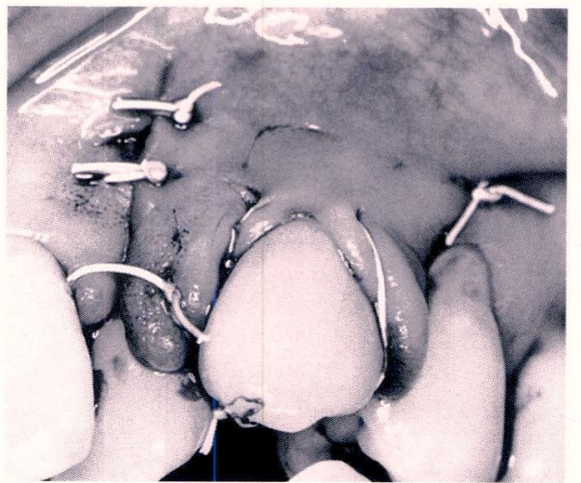

図 5 フラップは減張切開により歯冠側へ伸展 した状態で, ePTFE膜を完全に被覆し て縫合する

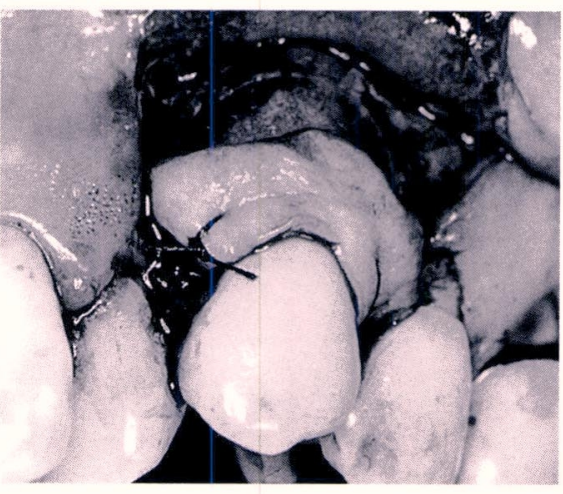

図 8 遊離結合組織移植片を C-E 境の位置で 縫合により固定する

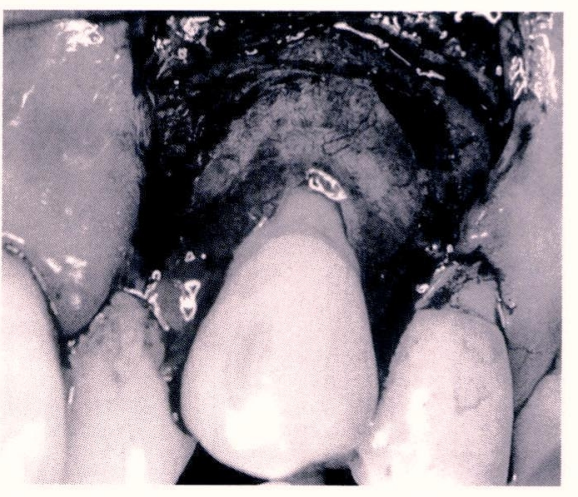

図6 術後6週でリエントリーを行い,ePTFE 膜を除去する. 露出根面に新生組織が認 められる

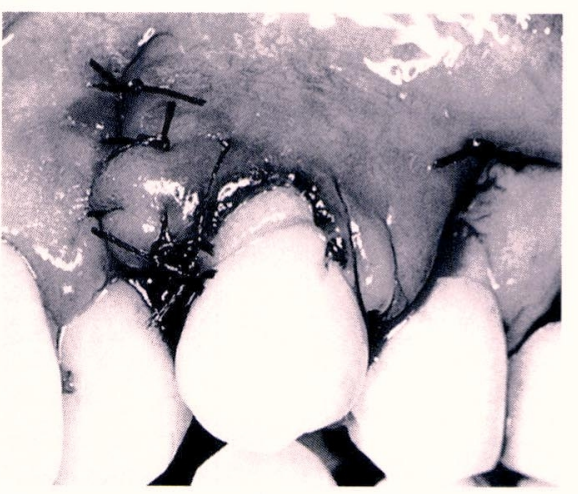

図 9 全層フラップは根尖側に戻して, 遊離結 合組織移植片をフラップと新生組織とで 挟み込むようにして縫合する

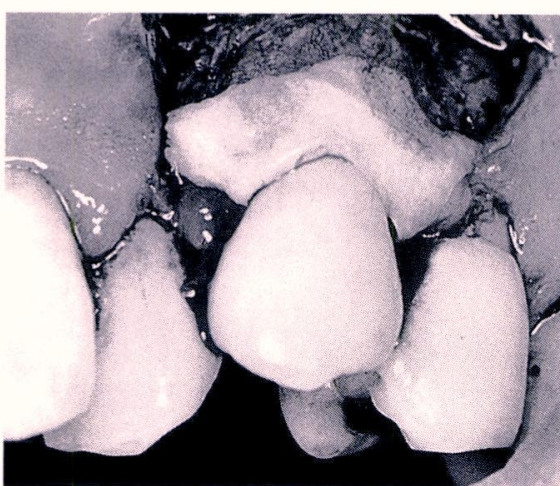

図7口蓋部上皮下から遊離結合組織移植片 を採取し, 形態を修正し, 新生組織上に 適合させる

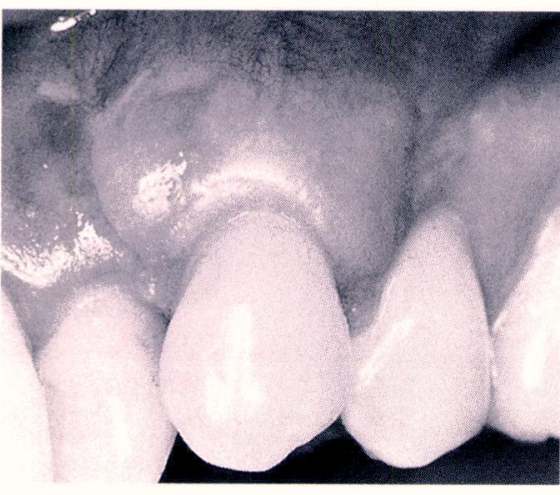

図 10 術後 12 か月の状態. 露出根面は十分 な量の角化組織を伴って, 完全に被覆 されている
ePTFE膜を被覆できるまで行い，フラップを縫合する（図 5).

歯周包帯は $\mathrm{ePTFE}$ 膜により形成した組織再生のためのス ペースを確保するため，通常は行わない。

\section{（5）術後の管理}

術後はペニシリン系抗生剂（タカシリン®；メクト，東 京） $1,000 \mathrm{mg} ， 1$ 日量を分 4 で 5 日間投与，創面のブラッシ ングは禁止し， $0.02 \%$ 塩化ベンゼトニウム溶液（ネオステ リングリーン®；日本歯科薬品，東京）による洗口を指示 した。ささに二次手術までの6週間は毎週患者を来院させ， 創面の清掃, 消毒を行った.

\section{2) 二次手術}

（1）フラップの剥離と ePTFE膜の除去

一次手術後 6 週で二次手術を行う。フラップを剥離し, ePTFE膜を固定した縫合糸を切断して膜を慎重に取り除 く. 露出していた歯根面は歯頸部の一部を除いて新生組織 によって被覆されている(図6).
（2）遊離結合組織移植片の採取と新生組織上への移植

口蓋部上皮下から遊離結合組織移植片を採取し，トリミ ングの後，新生組織上に移植する（図7，8）.

（3）全層フラップの根尖側への復位と縫合

剥離したフラップは, 遊離結合組織移植移植片を新生組 織とフラップとで挟み込むような形で縫合する.このとき， 一次手術で歯冠側に伸展させたフラップは根尖側方向，す なわち，元の位置に戻した状態で縫合する（図 9).

\section{（4）術後の管理}

二次手術後は歯周包帯を行うほかは，一次手術と同様の 術後管理を行う。図10は，左側犬歯の術後12か月後の状 態を示す．完全な根面被覆が得られている。図 $11 \sim 15$ は，右側犬歯の治療経過を示す，左側と同様に深くて広い 歯根露出と歯根の突出が認められたが, GTR-上皮下結合 組織移植併用法により，完全な根面被覆が得られている. 


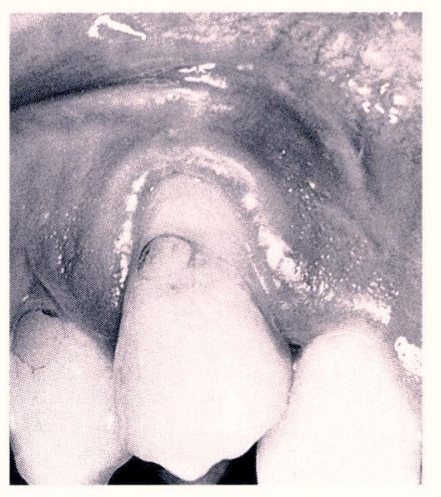

図 11 右側上顎犬歯の術前の状 態

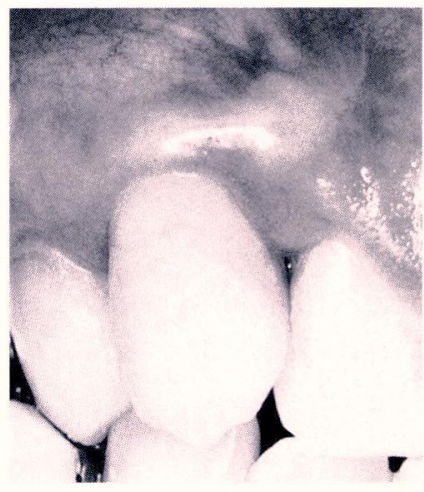

図 15 術後 12 か月における右 側上顎犬歯の状態. 左側 同様に完全な根面被覆が 得られている

\section{結 果}

\section{1. 肉眼および臨床所見}

歯根の突出を伴う上顎犬歯は両側ともに完全な露出根面 の被覆ができ，術前に訴えていた知覚過敏も改善した。さ らに，根面を被覆している組織は色調，性状ともに周囲組 織とよく調和しており, 角化組織の状態を呈している。ま た, 術前と比較して, 両側ともに口腔前庭の拡張と角化組 織の増加が認められる。術後 12 か月の時点において, 根面 被覆に関する術後の併発症や後戻りなどは認められない。

\section{2. 歯周病学的パラメーターの変化}

術後 12 か月における歯周病学的パラメーターの測定值 を表己に，術前と比較した術後 12 か月の歯周病学的パラ メーターの変化量を表了に示す。

歯周ポケット深さ（PD）の測定結果から，術後 12 か月 においては右側犬歯は術前,術後ともに $1.5 \mathrm{~mm}$ と変化なし. 左側では 1.0 から $0.5 \mathrm{~mm}$ となり，0.5 mmの減少を示した.

プロービングアタッチメントレベル (PAL) は，右側犬 歯は 6.0 から $1.5 \mathrm{~mm}$ に減少, 左側では同様に 6.0 から $0.5 \mathrm{~mm}$ に減少し, 右側で $4.5 \mathrm{~mm}$, 左側で $5.0 \mathrm{~mm}$ と大幅なプロービ
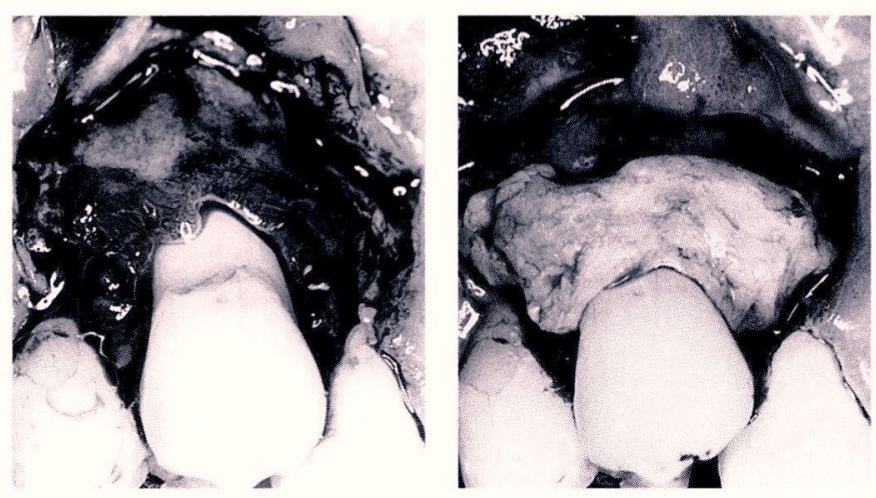

図 13 リエントリー手術での膜 除去後の新生組織の状態 合

表己 術後 12か月における 3 3 3 歯周病学的パラメーター $(\mathrm{mm})$

\begin{tabular}{|c|l|l|}
\hline 歯周病学的パラメーター & 3 & $\mid 3$ \\
\hline PD & 1.5 & 0.5 \\
PAL & 1.5 & 0.5 \\
RD & 0 & 0 \\
KTW & 5.0 & 6.5 \\
\hline
\end{tabular}

PD : probing pocket depth

PAL : probing attachment level

RD : recession depth

KTW : keratinized tissue width

表 3 術前と比較した術後 12 か月における $3 \mid 3$ の歯周病学的パラ メーターの変化量 $(\mathrm{mm})$

\begin{tabular}{|l|l|l|}
\hline & $\underline{3}$ & $\underline{3}$ \\
\hline PR & 0 & 0.5 \\
PAG & 4.5 & 5.5 \\
RR & 4.5 & 5.0 \\
KTI & 3.0 & 4.5 \\
\hline
\end{tabular}

PR : probing pocket reduction

PAG : probing attachment gain

RR : recession reduction

$\mathrm{KTI}$ : keratized tissue increase

ングアタッチメントゲインが得られた。

重直的歯肉退縮量 (RD) の測定結果からは，右側犬歯は 4.5 から $0 \mathrm{~mm}$, 左側では 5.0 から $0 \mathrm{~mm}$ と両側ともに術後 12 か月の時点で $100 \%$ の根面被覆が得られている.

角化組織の幅 $(\mathrm{KTW})$ は, 右側犬歯で 2.0 から $5.0 \mathrm{~mm}$ の 増加, 左側でも 2.0 から $6.5 \mathrm{~mm}$ と増加し, 右側で $3.0 \mathrm{~mm}$, 左 側で $4.5 \mathrm{~mm}$ の角化組織の増加を示している。

\section{考 察}

歯肉退縮を生じた突出歯根に対する根面被覆は, Miller の歯肉退縮の分類 ${ }^{19)}$ では class III に分類され, 十分な根面 被覆は期待できないとされている。これは, 被覆しようと 
する根面が周囲歯槽骨から突出している場合に，突出した 歯根によって移植片と移植床との密着が阻害され, その結 果, 移植片の生着に最も重要な条件である移植片への血液 供給が得られないためである ${ }^{20,211}$ 。ささらに歯根の突出は, 移植片を適合させるために必要な露出根面の平坦化を困難 にし, 移植床との間に死腔が形成される。したがって, 突 出歯根に対する根面被覆は, その突出の程度によっても予 知性が左右されると考えられる。また，GTR法を用いた 根面被覆の立場から考えてみた場合, 上皮下結合組織移植 による根面被覆とは異なり， 口腔内からの歯肉や結合組織 などの移植材を用いないことから, 術式の中で移植片の生 着に関与する血液供給は考慮する必要がない. GTR法に おける成功のための条件は, 再生組織を形成するためのス ペース確保と維持, さらに膜の確実な固定やフラップによ る膜の完全な被覆である ${ }^{22}$. そのため, 2 もしくは3壁性 垂直性骨欠損や 2 度の根分岐部病変がスペースの確保や維 持に有利なため, 最適応症とされている ${ }^{23)}$. GTR 法を用い た歯肉退縮による露出根面を考えた場合, 新生組織を形成 するためのスペース確保や維持は難しく, 特に歯根の突出 を伴う場合には非常に困難となる. そのため, 膜と露出根 面との間のスペースを確保するために, passing sutureによ って膜を桶状に彎曲させたり ${ }^{13)}$ ，チ多強化膜（titaniumreinforced membrane ${ }^{24)}$ を用いて膜成型後の強度自体を向上 させる方法などが用いられている。したがって, 突出歯根 を伴う露出根面の被覆に対しては，上皮下結合組織移植掞 よびGTR法のどちらも一長一短があり, それぞれの方法 単独では十分な治療効果は期待できないと考えられる.

一方, GTR-上皮下結合組織移植併用法は, 一次手術時 にGTR 法を用いることで露出根面に歯周組織再生の期待 できる新生組織を形成させ，二次手術時に，形成された新 生組織上に結合組織を移植する方法である。突出歯根への GTR 法の適用は, 前述したようにスペース確保の点で十分 な新生組織量が得られない場合が多い. そこで, 二次手術 時に結合組織移植を行うことで不足した新生組織を補い， 十分な根面被覆を可能にしている。 また, 結合組織移植片 は, 血管新生の旺盛な新生組織や周囲組織, さらに剥離し たフラップなどから十分な血液供給を受けることができ， 移植片の生着に有利となる．新生組織上への結合組織の移 植はさらに, フラップの歯冠側への伸展による口腔前庭の 狭小化を防止し, 角化組織の増加にも効果的である.これ は, 口腔前庭が浅く, かつ角化組織の喪失した状態での根 面被覆に非常に効果的であることを示唆している.

上顎両側犬歯の突出歯根による歯肉退縮にGTR-上皮下 結合組織移植併用法を用いて根面被覆を行い, 歯周病学的
パラメーターによってその治療効果を判定した結果，歯周 ポケット深さは術後 12 か月では変化なし，あるいはわずか に減少した。これは術後12か月間を通して, 歯肉の炎症が なく推移していることを示している.プロービングアタッ チメントレベルの診査からは, 右側犬歯で $4.5 \mathrm{~mm}$, 左側で は $5.5 \mathrm{~mm}$ のアタッチメントゲインを認めた。これは, これ までの GTR 法を用いた根面被覆の研究結果 ${ }^{15)}$ からもわか るように，露出根面への新付着の形成が期待できると考え られる. 垂直的歯肉退縮量は術後 12 か月では両側ともに $0 \mathrm{~mm}$ であった。これは両側ともに $100 \%$ の根面被覆率を示 しており，GTR法と上皮下結合組織移植法を併用した根面 被覆法としての予知性の高さを示唆しているものと考えら れる.角化組織の幅は, 右側で $3.0 \mathrm{~mm}$, 左側では $4.5 \mathrm{~mm}$ の 増加を示した. GTR法単独では術後に有意な角化組織の増 加は望めないことから 16 18), 結合組織移植が角化組織の増 大に大きく関与していると考えられる。

\section{結 論}

根面被覆を困難にしている要因の一つである唇側への突 出歯根の根面被覆に対し, GTR 法と上皮下結合組織移植 を併用した根面被覆法を行い, その治療効果について検討 した。その結果，

（1）術後12か月において歯周ポケット深さ（PD）は, 右 側犬歯は変化なし. 左側では $0.5 \mathrm{~mm}$ の減少を示した。

（2）プロービングアタッチメントレベル（PAL）の診査 から, 右側犬歯は $4.5 \mathrm{~mm}$, 左側で $5.0 \mathrm{~mm}$ のアタッチメ ントゲインが認められた。

（3）重直的歯肉退縮量 (RD) の測定結果からは, 両側と もに $100 \%$ の根面被覆が得られた。

（4）角化組織の幅（KTW）は，右側犬歯で $3.0 \mathrm{~mm}$, 左 側でも $4.5 \mathrm{~mm}$ の增加を示した.

（5）GTR-上皮下結合組織移植併用法は，突出歯根や口 腔前庭の狭小，さらに角化組織の莒失したような悪条 件下での根面被覆に効果的であることが示唆された。

\section{参考文献}

1) Allen, E.P., Miller, P.D.Jr. : Coronal positioning of existing gingiva: Short term results in the treatment of shallow marginal tissue recession. J. Periodontol., $60: 316-319,1989$.

2) Bouchard, P., et al : Subepithelial connective tissue grafts in the treatment of gingival recessions. A comparative study of 2 procedures. J. Periodontol., 65 : 929-936, 1994.

3) Lang, N.P., Loe, H. : The relationship between the width of keratinized gingiva and gingival health. J. Periodontol., 43 : 623-627, 1972. 
4) Jordan, H.V., Summey, D.L. : Root surface caries : Review of the literature and significance of the problem. J. Periodontol., $44: 158,1973$.

5) Miller, P.D. : Regenerative and reconstructive periodontal plastic surgery. Dent. Clin. North. Am., 32 (2) : 287-306, 1988.

6) Langer, B., Langer, $L:$ Subepithelial connective tissue graft technique root coverage. J. Periodontol., 56 : 715-720, 1985.

7) Harris, R.J. : The connective tissue with partial thickness double pedicle graft : A predictable method of obtaining root coverage. J. Periodontol., 63 : 477-486, 1992.

8) Nelson, S. : The subpedicle connective tissue graft : A bilaminar reconstructive procedure for the coverage of denuded root surfaces. J. Periodontol., 58 : 95-102, 1987.

9) RaetZke, P.B. : Covering localized areas of root exposure employing the "emvelope" technique. J. Periodontol., 56 : 397 402, 1985.

10) Bruno, J.F. : Connective tissue graft technique assuring wide root coverage. Int. J. Perio. Rest. Dent., 14 : 127-137, 1994.

11) Borghetti, A., Louise, F. : Controled clinical evaluation of the subepithelial connective tissue graft for the coverage of gingival recession. J. Periodontol., 65 : 1107-1112, 1994.

12) Tinti, C., Vincenzi, G. : The treatment of gingival recession with "guided tissue regeneration" procedures by means of Gore-Tex membranes. Quintessence Int., 6 : 465-468, 1990.

13) PiniPrato, G., et al. : Guided tissue regeneration versus mucogingival surgery in the treatment of fuman buccal gingival recession. J. Periodontol., 63 : 919-928, 1992.

14) Tinti, C., et al. : Guided tissue regeneration in the treatment of human facial recession. A 12-case report. J. Periodontol., 63 : 554-560, 1992.

15) Cortellini, P., Clauser, C., Pini Prato, G. : Histologic assessment of new attachment following the treatment of a human buccal recession by means of a guided tissue regeneration procedure. J. Periodontol., 64 : 387-391, 1993.
16）申 基吉吉，宮田 隆，池田克己：露出歯根面の被覆に関 する臨床的研究 1. GTR法を用いた歯肉退縮の治療と その臨床的評価. 日歯周誌, $37: 539-549,1995$.

17) Pini Prato, Clauser, C., Cortellini, P. : Guided tissue regeneration versus mucogingival surgery in the treatment of human buccal recessions. A 4-year follow-up study. J. Periodontol., $67: 1216-1223,1996$.

18) Shin, K., et al. : Effect of guided tissue regeneration in the treatment of labial gingival recessions. J. Meikai Univ. Sch. Dent., 25 : 224-230, 1996.

19) Miller, P.D. Jr. : A classification of marginal tissue recession. Int. J. Perio. Rest. Dent., $2: 8-13,1985$.

20) Miller, P.D. Jr. : Root coverage using the free tissue autograft citric acid application. Part I : Technique. Int. J. Perio. Rest. Dent., 2 : 65-70, 1982.

21) Miller, P.D. Jr. : Root coverage using the free soft tissue autograft following citric acid application. III. A succesfull and predictable procedure in deep- wide recession. Int. J. Perio. Rest. Dent., 5: 14-37, 1985.

22）申 基吉吉: 露出歯根面に対する GTR法による根面被覆. the Quintessence, $14: 2647-2657,1995$.

23）申 基喆, 吉江弘正 : 再生治療のための診断II. 宮田 隆, 吉江弘正 編著：歯周病診断のストラテジー. 第 1 版 : 102-111, 医歯薬出版 (東京), 1999.

24) Tinti, C., Vincenzi, G. : Expanded polytetrafluoroethylene titanium-reinforced membranes for regeneration of mucogingival recession defects. A 12- case reports. J. Periodontol., 65 : 10881094, 1994.

\section{別刷請求先：申 基吉吉}

明海大学歯学部歯周病学講座 